\title{
Engaging publics: writing as praxis
}

cultural geographies

2014, Vol 2I(I) 153-157

(C) The Author(s) 2012

Reprints and permissions:

sagepub.co.uk/journalsPermissions.nav DOI: I0.I I77/|4744740I2462535

cgj.sagepub.com

@SAGE

\section{Rob Kitchin}

NIRSA, NUI Maynooth, Ireland

\begin{abstract}
Geographers have long debated for whom and for what ends academics should research and publish, how geographical knowledge is produced, and the use and value of such knowledges. This paper contributes to these debates through a discussion of an on-going project concerning the financial crisis in Ireland and its legacy of 'ghost estates'. The analysis is framed with respect to Michael Burawoy's taxonomy of forms of scholarly knowledge production and details the use of 10 forms of writing praxis, aimed at engaging a variety of audiences. The paper demonstrates that the classes in Burawoy's taxonomy are far from mutually exclusive, and illustrates how geographical scholarship can make an impact in a variety of registers.
\end{abstract}

\section{Keywords}

audience, critical geography, ghost estates, policy, public geography, writing

\section{Introduction}

As an academic concerned with not only researching the world, but actively engaging in the transformation of society in just and fair ways, for the past 15 years I have been examining and employing critical academic praxis of various kinds, including action and advocacy research, participatory approaches, policy work, and knowledge transfer of various kinds. ${ }^{1}$ The praxis - the specific techniques of engagement - involved in these projects is diverse and extend beyond traditional forms of research, journal publication and university teaching, to include the delivery of training programmes to practitioners, policy makers and politicians; engaging in public debate via the media and non-academic fora; performing advocacy roles for communities; sitting on state boards and working with and advising stakeholder groups; drafting and commenting on public policy; building public research infrastructures (the All-Island Research Observatory; Irish Qualitative Data Archive); and producing creative works.

In this short paper, I discuss how these different forms of praxis have coalesced in conjunction with and through a set of 10 forms of writing with respect to one specific project. In so doing, the

\section{Corresponding author:}

Rob Kitchin, NUI Maynooth, Maynooth, County Kildare, Ireland.

Email: rob.kitchin@nuim.ie 
paper aims to contribute to debates within Geography regarding public geographies, ${ }^{2}$ and questions concerning for whom and for what ends academics research and write, how geographical knowledge is produced, and the use and value of such knowledges. ${ }^{3}$ Disciplinary praxis, Michael Burawoy argues, ${ }^{4}$ is defined principally through the form of knowledge produced (instrumental or reflexive) and its intended audience (academic or extra-academic) (see Table 1 as adapted for Geography). What I want to illustrate in this paper is that classes in Burawoy's taxonomy are far from mutually exclusive, and how the 10 forms of writing praxis I discuss sought to produce knowledge and effects within three of his classes (critical geography; applied (policy) geography; participatory and public geographies).

The project I focus on concerns the phenomena of so-called 'ghost estates' in Ireland. These are unfinished housing developments or new estates with high levels of vacancy that populate the Irish landscape in the wake of the global financial crisis (GFC). Ireland was particularly badly hit by the GFC as it triggered the collapse of a massive property bubble, leading to a systemic banking failure, and ultimately a financial bailout from the troika of the IMF/ECB/EU to avoid a sovereign debt default. As of October 2011, there were 2876 such estates in the country consisting of 122,048 housing units (36,510 of which are vacant or under-construction) ${ }^{5} 2066$ of these estates have either unfinished units or incomplete roads, paths, lighting or sewage works, and of these 1822 are inactive (no development work is taking place). These estates are part of a wider issue of oversupply and, in total, 289,541 units were classed as vacant in Ireland in 2011 from a total housing stock of $1,994,845 .{ }^{6}$ Indeed, there are large swathes of the country where housing vacancy is in excess of 25 per cent. Not unsurprisingly, the economic and property crisis has dominated political, media and popular discourse in Ireland, as well as attracting the attention of the international media interested in the country itself and the wider European financial and political crisis.

Over the past couple of years I have endeavoured to engage with and participate in this wider discourse, as well as academic debates, through 10 forms of writing praxis: fiction, blog posts, newspaper op eds, email correspondence, policy papers, policy consultation, a television documentary script, powerpoint slides, academic papers, and grant applications. These writing praxes have built on and fed off each other to create an assemblage of written works that have performed both individually and collectively to seek policy change that would aid those residents living on

Table I. Forms of geographical knowledge production and praxis.

\begin{tabular}{lll}
\hline & Academic audience & Extra-academic audience \\
\hline $\begin{array}{ll}\text { Instrumental knowledge } \\
\text { - Knowledge }\end{array}$ & Professional Geography & Applied (Policy) Geography \\
- Legitimacy & Theoretical/empirical & Concrete \\
- Accountability & Scientific norms & Effectiveness \\
- Pathology & Peers & Clients/patrons \\
*Politics & Self-referentiality & Servility \\
Reflexive knowledge & Professional self-interest & Policy intervention \\
& Critical Geography & Participatory and Public \\
- Knowledge & & Geography \\
- Legitimacy & Foundational & Communicative \\
- Accountability & Moral vision & Relevance \\
- Pathology & Critical intellectuals & Designated publics \\
*Politics & Dogmatism & Faddishness \\
\hline
\end{tabular}


such estates and to provide a counter-discourse to that being propagated by the property and development sector with respect to the state of the property market. Nearly all of the work on the project was unfunded or was funded indirectly.

Perhaps somewhat unusually, one of the initial impetuses for the academic research was a piece of fiction. For a number of years I have been writing short stories and novels, mostly in the crime genre. $^{7}$ My first two novels ${ }^{8}$ are police procedurals set in Ireland. For the third novel in the series I decided to concentrate on property development and planning corruption, focusing on the murder of an estate agent in the aftermath of the Irish property crash. I began writing the novel in December 2008 and had a first full draft in August 2009. It has since been through various drafts and edits and been read by agents and publishers, though it has not yet been published. In undertaking research for the book I started to investigate housing and planning in Ireland and soon realized that there was a major issue brewing that needed more academic attention. This led on to an academic piece of work starting in November 2009 with two colleagues, Peter Foley and Justin Gleeson. It was known at the time that Ireland had some serious issues with respect to its housing market, what was not known was the extent of the problem with respect to the number and status of so-called ghost estates or the level of housing oversupply (housing statistics in Ireland are poor; for example, there is no official property database). Using various sources of data, we calculated estimates relating to both estates and oversupply that we then published through a second form of writing praxis - blog posts.

In November 2009 several academic geographers from across the Irish university system established a public geographies blog, IrelandAfterNAMA. ${ }^{9}$ The idea was to provide timely and informed commentary, data analysis and interpretation, and observations regarding breaking news and ongoing issues with respect to the unfolding crisis in Ireland and how it was playing out geographically. In January 2010 we posted the first of our posts about ghost estates and housing oversupply. The second of these posts was picked up by the national broadcaster and appeared as the third item on that evening's news. We are still writing regular blog posts regarding housing and planning in Ireland. As of May 2012, it had received over 317,000 unique visits, with 278 subscribers, including a number of local and national journalists.

Our blogging led into the third and fourth kind of writing praxis: composing op ed pieces for newspapers and corresponding with journalists and interested parties (including the public, specialist interest groups, and government departments and agencies), along with other communicative praxes such as telephone conversations and radio/TV interviews. Our blog posts created a fierce public debate about the property crash in Ireland, its causes, its extent, its effects and what to do about it. Our data and analysis was publicly challenged by a number of interest groups, and we even received a number of abusive phone calls. On the one hand then, we were writing to inform the public about the situation and on the other to defend our research. As the story of ghost estates broke internationally, in tandem with Ireland becoming the focus of intense international political and financial scrutiny, we were approached by a number of overseas journalists for information. To date our research has been cited in the local, national and international media over 350 times and appeared uncited countless other times. The public debate led to the Department of Environment, Heritage and Local Government (as it was at the time) to conduct a national housing development survey and to produce a manual for dealing with unfinished estates.

This in turn led to other forms of writing praxis. Over the past two years we have produced a number of powerpoint presentations, blending graphs, tables and maps with bullet-pointed text and presented the material a number of times to different academic, professional body and public fora. We also drafted a fairly lengthy report, A Haunted Landscape, published in July $2010 .{ }^{10}$ This report was co-written with Justin Gleeson, Karen Keaveney and Cian O'Callaghan, and sought to 
contextualize and explain the property crash within a neoliberal framing for an informed lay audience. We have also written policy submissions to government departments on draft policy concerning unfinished estates (along with Brendan Gleeson).

Interestingly, there was a media bidding war for an exclusive to cover the launch of the Haunted Landscape report. We chose to go with Prime Time, Ireland's leading investigative reporting television programme. One of our conditions was that we would write and present a short documentary (12 minutes) and that we had editorial control over the message. This necessitated writing a script for the narration. This script proved to be very fluid, changing as we interviewed people and as the programme was edited. The programme was broadcast on RTE1 on 29 July 2010, followed by a panel debate including the planning minister, and led to a fresh wave of media work. To date we have undertaken 12 television interviews and over 50 radio interviews.

In turn, the project led on to two more academic forms of writing: academic papers for internationally refereed journals and grant applications. Papers arising from the project have been submitted to Transactions of the Institute of British Geographers (mapping estates), Environment and Planning A (Irish neoliberalism), and the International Journal of Urban and Regional Research (unfinished estates). ${ }^{11}$ These papers are very much aimed at an academic audience and seek to draw out the conceptual implications of the empirical work. In turn, Cian O'Callaghan refined and extended some of the material in a successful grant application to the national research council (Irish Research Council for Humanities and Social Sciences) and he has also written the text to accompany professional artist exhibitions.

The 'ghost estates' project then evolved over time to employ a diverse set of writing and other praxes to contribute to three of Burawoy's forms of disciplinary knowledge production and praxis - progressing along a trajectory of personal interest to public geographies to applied policy geographies to critical geographies. The forms of writing praxis (fiction, op eds, email, presentations, policy documents, television script, academic papers) were central to this progression as the style (in terms of language, phrasing, structuring and length) of writing employed had to be tailored to different media (book, internet, policy reports, television, journals) and audiences (general public, journalists, policy makers and implementers, special interest groups, academics) and to communicate different but related knowledges and messages. These different forms of writing fed off and into each other, working in concert, creating an evolving discursive message in conjunction with other forms of communication - graphs, tables, maps, radio/TV interviews, presentations, telephone conversations. Beyond writing in new ways and for extended audiences (both in terms of types of audience and their location [local, national, international]), the project threw up other challenges, such as providing just-in-time analysis (we would often undertake and publish analysis of new data or policy on the day it was released), reacting to on-going debate, and replying to comments on the blog in a timely fashion. Some forms of writing praxis then had to be done quickly and to tight deadlines, something that seems to run counter to scholarly reflection and rigour, but vital if one is to engage in these kinds of public geographies. Somewhat ironically, the only form of writing discussed here that is not presently in the public domain is the original piece of fiction that provided a platform for my initial interest. If the novel is published then this will work to communicate some of the issues relating to the property bubble and crash to the general public through a new medium. ${ }^{12}$

Whether fiction, news stories, blog posts, reports, television or radio scripts, public presentations, what the 'ghost estates' project has highlighted is that there are a number of writing praxes that can be productively employed that extend beyond conventional academic papers and books. Collectively, these praxes can to be used to create new public geographies that seek and enact progressive change. As a discipline we need to explore and utilize these writing praxes so that they become a regular part of our wider disciplinary praxis. 


\section{Funding}

This research received no specific grant from any funding agency in the public, commercial, or not-for-profit sectors, though elements were supported indirectly through the Programme for Research in Third Level Institutes, Cycle 4, administered by the Higher Education Authority.

\section{Notes}

1. See, for example, D. Fuller and R. Kitchin (eds), Radical Theory, Critical Praxis: Making a Difference Beyond the Academy? (Kelowna, BC: Praxis E-Press, 2004), <http://www.praxis-epress.org/rtcp/contents.html>; J. Gleeson, R. Kitchin, B. Bartley, J. Driscoll, R. Foley, S. Fotheringham and C. Lloyd, The Atlas of the Island of Ireland (Maynooth: AIRO/ICLRD, 2008); R. Kitchin, 'Participatory Mapping of Disabled Access', Cartographic Perspectives, 42, 2002, pp. 50-62; R. Kitchin and P.J. Hubbard (eds), 'Research, Action and “Critical” Geographies', Area, 31(3), 1999, pp. 195-246.

2. D. Fuller and A. Askins, 'Public Geographies II: Being Organic', Progress in Human Geography, 34(5), 2010, pp. 654-67; K. Ward, 'Geography and Public Policy: Towards Public Geographies', Progress in Human Geography, 30(4), 2006, pp. 495-503.

3. R. Kitchin and J. Sidaway, 'Geography's Strategies', Professional Geographer, 58(4), 2006, pp. 485-91; L.A. Staeheli and D. Mitchell, 'The Complex Politics of Relevance in Geography', Annals of the Association of American Geographers, 95, 2005, pp. 357-72.

4. M. Burawoy, 'For Public Sociology', American Sociological Review, 70, 2005, pp. 4-28.

5. Department of Environment, Community and Local Government, Summary Report of 2011 National Housing Survey, $<\mathrm{http}: / / w w w . h o u s i n g . i e / O u r-S e r v i c e s / U n f i n i s h e d-H o u s i n g-D e v e l o p m e n t s / S u r v e y-o f-$ Unfinished-Housing-Developments.aspx $>$.

6. Central Statistics Office, This is Ireland - Highlights from Census 2011, Part 1 (Dublin: CSO, 2012).

7. See $<\mathrm{http}: / /$ theviewfromthebluehouse.blogspot.com/>.

8. R. Kitchin, The Rule Book (Brighton: Pen Press, 2009); R. Kitchin, The White Gallows (Brighton: Indepenpress, 2010).

9. See $<$ http://irelandafternama.wordpress.com/>.

10. R. Kitchin, J. Gleeson, K. Keaveney and C. O'Callaghan, 'A Haunted Landscape: Housing and Ghost Estates in Post-Celtic Tiger Ireland', NIRSA Working Paper 59, 2010, <http://www.nuim.ie/nirsa/ research/documents/WP59-A-Haunted-Landscape.pdf $>$.

11. R. Kitchin, J. Gleeson and M. Dodge, 'Towards a New Epistemology for Cartography', Transactions of the Institute of British Geographers, in press; R. Kitchin, C. O'Callaghan, M. Boyle, J. Gleeson and K. Keaveney, 'Placing Neoliberalism: The Rise and Fall of Ireland's Celtic Tiger', Environment and Planning A, 2012, 44, pp. 1302-1326; R. Kitchin, C. O'Callaghan, and J. Gleeson, 'The New Ruins of Ireland? Unfinished estates in the Post-Celtic Tiger Era', International Journal of Urban and Regional Research, in review.

12. Winterland by Alan Glynn (London: Faber, 2009), The Rage by Gene Kerrigan (London: Harveill Secker, 2010), Ghost Town by Michael Clifford (Dublin: Hachette, 2012), and Broken Harbour by Tana French (Dublin: Hachette, 2012) also deal with the property crash and its aftermath from a crime genre perspective.

\section{Author biography}

Rob Kitchin is Director of the National Institute for Regional and Spatial Analysis at the National University of Ireland, Maynooth. He has published widely across the social sciences, including 20 books and over 100 articles and book chapters. He is editor of the international journals, Progress in Human Geography and Dialogues in Human Geography, and for 11 years was the editor of Social and Cultural Geography. He was the editor-in-chief of the 12 volume, International Encyclopedia of Human Geography. He has undertaken research for a wide range of bodies including government departments, semi-stage agencies, NGOs, and community groups. 